Ourselves and Computers 


\section{Information Systems Series}

Series Editor: Professor I. O. Angell

Computer Security Within Organizations

Adrian R. Warman

Developing Information Systems

Concepts, Issues and Practice

Chrisanthi Avgerou and Tony Cornford

Effective Systems Design and Requirements Analysis

The ETHICS Approach

Enid Mumford

Information in Action

Soft Systems Methodology

Lynda Davies and Paul Ledington

Information Systems Management

Opportunities and Risks

Ian O. Angell and Steve Smithson

Ourselves and Computers

Difference in Minds and Machines

Aart Bijl

Understanding Information

An Introduction

Jonathan Liebenau and James Backhouse 


\title{
Ourselves and Computers
}

\author{
Difference in Minds and Machines
}

\author{
Aart Bijl \\ Edinburgh Computer Aided Architectural Design \\ Department of Architecture, Unversity of Edinburgh
}

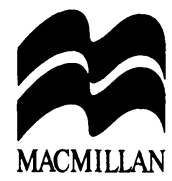


All rights reserved. No reproduction, copy or transmission of this publication may be made without written permission.

No paragraph of this publication may be reproduced, copied or transmitted save with written permission or in accordance with the provisions of the Copyright, Designs and Patents Act 1988, or under the terms of any licence permitting limited copying issued by the Copyright Licensing Agency, 90 Tottenham Court Road, London W1P 9HE.

Any person who does any unauthorised act in relation to this publication may be liable to criminal prosecution and civil claims for damages.

First published 1995 by

MACMILLAN PRESS LTD

Houndmills, Basingstoke, Hampshire RG21 2XS

and London

Companies and representatives

throughout the world

ISBN 978-0-333-64582-6

DOI 10.1007/978-1-349-13881-4

ISBN 978-1-349-13881-4 (eBook)

A catalogue record for this book is available from the British Library.

$\begin{array}{llllllllll}10 & 9 & 8 & 7 & 6 & 5 & 4 & 3 & 2 & 1\end{array}$

$\begin{array}{rrrrrrrrrr}04 & 03 & 02 & 01 & 00 & 99 & 98 & 97 & 96 & 95\end{array}$ 


\section{Contents}

$\begin{array}{ll}\text { Introduction } & 1\end{array}$

Using computers; Politics of IT; Philosophical dimension;

Contents; Readers

$1 \quad$ Pictures of ourselves $\quad 8$

Information $\quad 8$

$\begin{array}{lr}\text { Market ideology } & 10\end{array}$

Our way of knowing $\quad 15$

Orthodox system strategies $\quad 28$

An $I T$ Charter $\quad 38$

2 Knowing in Japan 41

Fresh insights 41

Approaches to logic $\quad 42$

Togetherness 47

Explanation $\quad 58$

Corporate behaviour $\quad 64$

interlude 1: Sound of language 77

3 Space between $Y e s$ and No $\quad 80$

Where interaction occurs $\quad 80$

What's in a concept? $\quad 82$

The 'real-world' assumption $\quad 93$

Logic-machines $\quad 98$

Artificial intelligence $\quad 107$

interlude 2: Conversation among engineers 116

4 Showing yourself 124

Sharing knowledge 124

Feeling and knowing 125

Knowledge and language $\quad 131$

Truth 143

Using logic 151

interlude 3: Conversation with a painter 158 
A way forward 166

Heidegger's everyday practices $\quad 167$

Expressionism to Post-Modernism 174

$\begin{array}{lr}\text { What we can do } & 179\end{array}$

$\begin{array}{lr}\text { What computers can do } & 189\end{array}$

'One-reality' paradigm 195

interlude 4: Holding onto our marbles 206

$\begin{array}{ll}\text { Conclusions } & 208\end{array}$

Knowledge; Technology; Information processing;

One reality

References and bibliography $\quad 216$

Index $\quad 220$

\section{Acknowledgements}

Grateful acknowledgement is made to the following for permissions to reproduce illustrations: Dresden State Art Collections (for Otto Dix works in Interlude 3); Academic Press (for Brachman figure in Chapters 1 and 3); Mandelbrot (in Ch. 1); Harra (in Ch. 2) - detailed references are included in the text.

Short text quotations (in accordance with fair dealing) are fully acknowledged in the text.

All reasonable efforts have been made to avoid infringing the rights of copyright owners; if any infringement has inadvertently occurred the publishers will make amends at the earliest opportunity. 